\title{
EFFECTS OF DIETARY PROTEIN-FAT DEFICIENCIES ON LACTATION AND SURVIVAL OF YOUNG IN LABORATORY MICE*
}

\author{
B. J. HIRT, H. T. GIER AND G. B. MARION \\ Kansas State University, Manhattan, Kansas
}

(Received 18th September 1967)

\begin{abstract}
Summary. Adult white mice were maintained on a proven laboratory chow to parturition, then on experimental feed for 20 days; young were weaned, placed on full feed, and mated at 60 days.

Casein, constituting 12, 10, 8 and $6 \%$ of an otherwise balanced food, resulted in survival of young to 20 days of $82,69,38$ and $4 \%$ of those born. Corn oil reduced from $10 \%$ for controls to $2.5 \%$, with $10 \%$ casein, resulted in $43 \%$ survival. Whole grain corn meal (9\% protein) was adequate for normal survival, but corn meal diluted with corn starch $2: 1$ maintained only $35 \%$ of the young to 20 days. Individual weight and litter weight was reduced comparably. Young from litters, in which less than half survived, recovered slowly, failed to reproduce until after 120 days of age ( $50 \%$ produced a litter by 150 days) and suffered loss of 40 to $60 \%$ of their young. The survivors of these litters were approximately 20 days older than controls before they reproduced (average 114 days of age) but maintained nearly $90 \%$ of their young to weaning.

Litters reduced to five on the day of birth were maintained to 20 days even on $8 \%$ casein and $2.5 \%$ fat, and all young matured normally.

Severe deficiencies of either fat or protein in the food of a lactating female resulted in reduced weight and number of young. Survivors were slow in maturing and produced small litters, with high mortality, through the second generation.
\end{abstract}

\section{INTRODUCTION}

The kind and amount of food available at different times during lactation either stimulates or inhibits the growth of the individual young and subsequently the population. Deficiencies of certain types of food have been shown to produce prenatal effects as well as postnatal maternal effects and thus influence inherent growth potential of both the individual and the population (Bateman, 1954). Lauckhart (1957) thought the effect resulted from nutritional deficiencies rather than actual starvation, manifested in reduced survival of young as well as lowered weights of offspring. French, Ingram, Knoebel \& Swift (1952) and Maynard \& Rasmussen (1942) found that $4.5 \%$ fat diets resulted in slower

* Contribution No. 409, Department of Zoology, and No. 680, Department of Dairy and Poultry Science, Kansas Agricultural Experiment Station, Manhattan, Kansas. 
growth of rat young than did diets containing $9 \%$ fat. Increased protein intake resulted in increased milk yields, producing bigger young at weaning. Lowered protein diets resulted in lower weaning weights rather than decreased numbers (Mueller \& Cox, 1946; Curtiss, 1953). Dietary protein must be above certain minimal levels for maximal growth of the young (Nelson, 1959).

Sauberlich \& Salmon (1955) reported that the growth of rats was decreased by dilution of casein with corn, possibly because of what they called 'tryptophane imbalance' of corn. Mitchell \& Smuts (1932) considered that the primary deficiency of corn protein is lysine, with a secondary deficiency of tryptophane. Cowley \& Griesel (1963) showed that a slight protein deficiency in the diet of the mother during pregnancy and lactation resulted in higher mortality and slower development of the young.

Chitty (1952) theorized that strife could affect survival of young, and if severe enough the effects could be transmitted to the next generation. Christian \& LeMunyan (1956) concluded that strife effect could be transmitted to the surviving progeny and affect their reproduction, which in turn affected the future of the population.

This study was conducted to determine some of the effects of inadequate diet on lactation and survival of young and whether nutritional effects on reproductive performance could be transmitted to succeeding generations.

\section{MATERIALS AND METHODS}

White mice of a Swiss strain were housed in stainless steel cages with exterior dimensions of $20 \times 15 \times 27.5 \mathrm{~cm}$. For breeding, two females and one male were

TABLE 1

COMPONENTS OF THE DIETS* USED IN THE REPRODUCTION STUDIES

\begin{tabular}{|c|c|c|c|c|c|c|c|}
\hline Group & \multicolumn{2}{|c|}{ Protein } & \multicolumn{2}{|c|}{ Fat $\ddagger$} & \multicolumn{2}{|c|}{ Carbohydrate } & $\begin{array}{c}\text { Fibre } \\
(\%)\end{array}$ \\
\hline I and IV-C & 12 & Casein & 10 & Corn & 40 & Dextrin & 23 \\
\hline $\begin{array}{ll}\text { II } \quad(1) \\
(2) \\
(3)\end{array}$ & $\begin{array}{r}10 \\
8 \\
6\end{array}$ & $\begin{array}{l}\text { Casein } \\
\text { Casein } \\
\text { Casein }\end{array}$ & $\begin{array}{l}10 \\
10 \\
10\end{array}$ & $\begin{array}{l}\text { Corn } \\
\text { Corn } \\
\text { Corn }\end{array}$ & $\begin{array}{l}42 \\
44 \\
46\end{array}$ & $\begin{array}{l}\text { Dextrin } \\
\text { Dextrin } \\
\text { Dextrin }\end{array}$ & $\begin{array}{l}23 \\
23 \\
23\end{array}$ \\
\hline III $\begin{array}{l}(1) \\
(2)\end{array}$ & $\begin{array}{l}12 \\
10\end{array}$ & $\begin{array}{l}\text { Casein } \\
\text { Casein }\end{array}$ & $\begin{array}{l}3 \\
2 \cdot 5\end{array}$ & $\begin{array}{l}\text { Corn } \\
\text { Corn }\end{array}$ & $\begin{array}{l}43 \\
45\end{array}$ & $\begin{array}{l}\text { Dextrin } \\
\text { Dextrin }\end{array}$ & $\begin{array}{l}25 \\
25\end{array}$ \\
\hline IV (1) & 8 & Casein & $2 \cdot 5$ & Corn & 47 & Dextrin & 20 \\
\hline $\mathrm{V}-\mathrm{C}$ & 9 & Corn & 4 & Corn & 73 & Starch & 2 \\
\hline $\mathrm{V} \quad\left(\mathbf{P}_{0}\right)$ & 6 & Corn & $2 \cdot 7$ & Corn & 80 & Starch & $1 \cdot 3$ \\
\hline $\begin{array}{l}\left(\mathrm{F}_{1}\right) \\
\left(\mathbf{F}_{2}\right)\end{array}$ & $\begin{array}{l}16 \\
16\end{array}$ & $\begin{array}{l}\text { Mixed } \dagger \\
\text { Mixed } \dagger\end{array}$ & $\begin{array}{l}8 \\
8\end{array}$ & $\begin{array}{l}\text { Cornt } \\
\text { Corn } \dagger\end{array}$ & $\begin{array}{l}50 \\
50\end{array}$ & $\begin{array}{l}\text { Starch } \dagger \\
\text { Starch } \dagger\end{array}$ & $\begin{array}{l}16 \dagger \\
16 \dagger\end{array}$ \\
\hline
\end{tabular}

* General Biochemical Vitamin supplement, $1 \%$, and Wesson salt mix, $5 \%$, were added to all diets except $\uparrow$.

$\dagger$ A proven laboratory pelleted feed.

\$ Commercial corn oil was used in Groups I to IV.

$\$$ Wood fibre, obtained from General Biochemicals, Cleveland, Ohio.

placed in each cage. Pregnant females were removed from the cage and placed alone in a cage with a fine wire mesh bottom with wood shavings for nesting 
material. Animals not on experiment were fed a proven laboratory chow formulated from natural feed stuffs and containing a minimum of $16 \%$ protein, $8 \%$ fat, $50 \%$ carbohydrate and adequate amounts of all known required minerals and vitamins. Experimental rations were formulated as needed from stock sources and served in 4-oz wide-mouth glass jars with screw caps, each of which was penetrated with a hole 16 to $18 \mathrm{~mm}$ diameter through which the mouse could insert its head or enter the jar.

The animals were divided into one control and four experimental groups (Table 1). Group II received a diet of decreasing amounts of protein. Group III received adequate protein but reduced fat. The animals were placed on experimental diet on the day of parturition and maintained for 20 days, then returned to the control diet.

To observe whether reduction of litters had any effect on weight and survival of offspring, five litters of Group IV-1 (8\% casein, $2.5 \%$ fat) and a comparable control group (Group IV-C) were reduced to five young each on the day of parturition.

Group V received corn meal as the sole protein source. The experimental diet contained two parts corn meal and one part corn starch $6 \%$ protein and $2.7 \%$ fat) with minerals and vitamins maintained at the control level. Group V-C (Table I), received corn meal fortified with minerals and vitamins and served as a control (protein $9 \%$, fat $4 \%$ ).

The number of young on the day of parturition was recorded. A separate group was maintained to obtain weights on the day of parturition, because handling mice during the first 3 days resulted in a high percentage of the young being killed by their mothers. Numbers and weights of the young were recorded on Days 5, 10,15 and 20.

Individuals of succeeding generations were maintained, mated at 60 days and allowed to reproduce to determine how long deficiency effects were detectable and whether those effects could be transmitted to offspring through lactating mothers.

\section{RESULTS}

The total food consumed could not be accurately determined because of the habit of some mice of kicking the food particles out through the hole in the top of the feed jar. The individual variations within groups exceeded the group variations and made weight of food remaining in the jar an unanalysable measure of food consumed. After a number of trials at determining the rate of food consumption by different groups, the effort was abandoned. The total quantity of food consumed was not measurably different in any of the groups for which measurements were attempted.

The control group of sixty females produced litters averaging 9.4 young of which $85 \%$ survived to weaning (Text-fig. 1). On Day 20, young mice averaged $8.5 \mathrm{~g}$ and litters averaged 70.6 g (Text-fig. 2). Nearly all losses occurred during the first 10 days of lactation and appeared to result primarily from lack of maternal care.

Group II females were successful in maintaining litters in proportion to the protein in their diet during lactation. Litters of the eleven females on $10 \%$ 


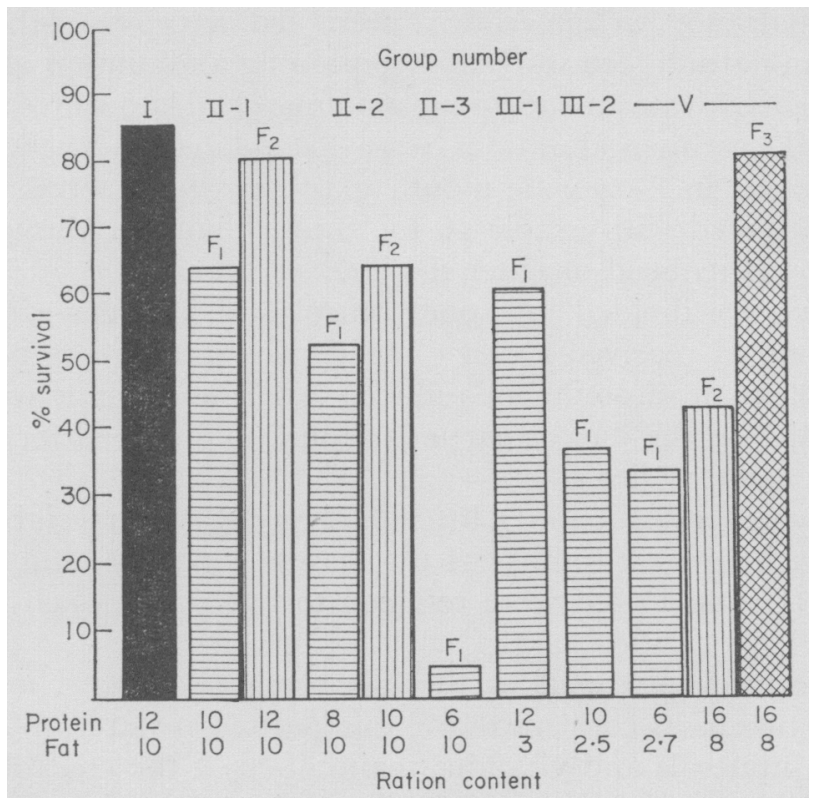

Text-rig. 1. Survival of suckling mice on various diets. Each column was determined by dividing the number of mice remaining on Day 20 by the number born in the group. Group designations, across the top of the graph, correspond to those in Table 1 . $F_{1}$ indicates the young nursed by mothers on the experimental diet. $F_{2}$ represents the first litter offspring of $F_{1}$ individuals and $F_{3}$ the offspring of $F_{2}$ individuals, all maintained on a balanced ration after the $F_{1}$ individuals were 20 days old. The percentage protein and fat content of the ration provided to the nursing females is given below the appropriate columns.

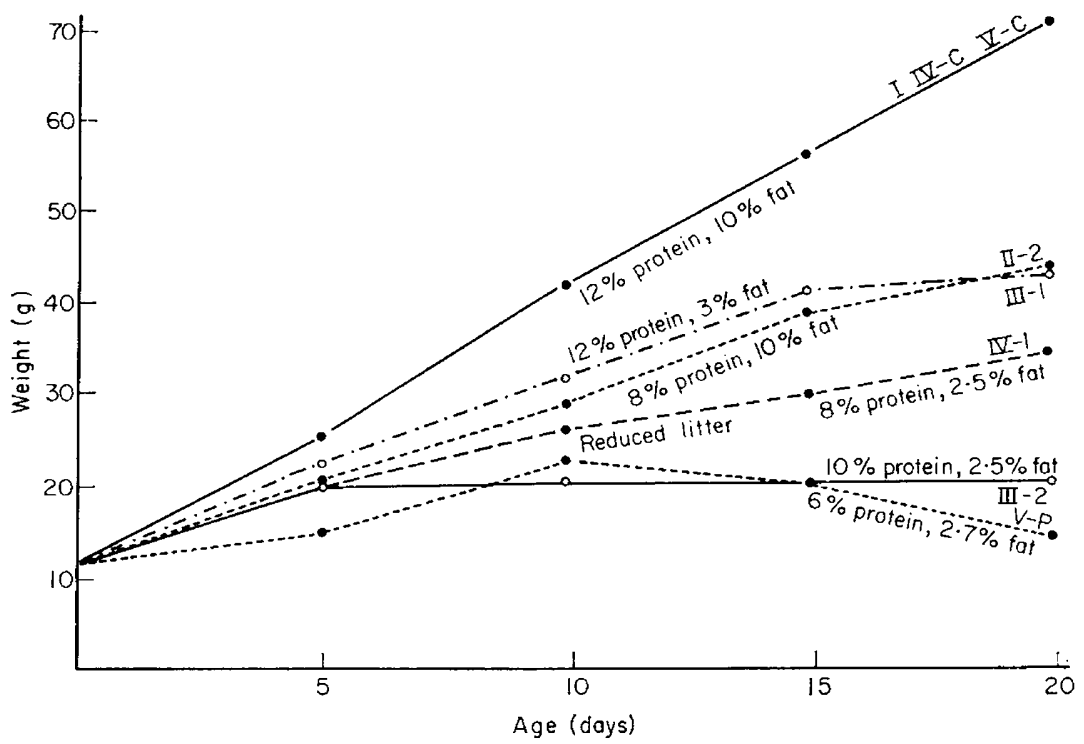

Text-FIG. 2. Litter weights of mice nursed by mothers maintained on various diets, as determined by weighing surviving members of the litter on the 5 th, 10 th, 15th and 20 th day after birth. Loss of total litters is not considered in this chart. The protein-fat constituents of the diet are written parallel to each weight graph, and the group, as given in Table 1 , is indicated at the right-hand end of each graph line. 
casein averaged $44.5 \mathrm{~g}$ at 20 days; individual young averaged $6.5 \mathrm{~g}$ and $66 \%$ survived to this time (Text-fig. 1). Reduction in survival was significant $(P<0.05)$. Six females from the preceding litters mated at 60 days of age produced litters within an average time of 84 days, averaging 9.6 young of which $81 \%$ survived with individual weights of $8.7 \mathrm{~g}$ and litter weights of $68 \mathrm{~g}$, essentially the same as the controls.

Reduction of the casein to $8 \%$ (Group II-2) resulted in survival rates of $52 \%$ of the young born to eleven females (Table 2) with individuals on Day 20

TABLE 2

GROUPS TESTED ON CONTROL AND DEFIGIENT DIETS, WITH SURVIVAL OF YOUNG AND LITTER WEIGHT AT 20 DAYS, AND AGE AT WHIGH $50 \%$ OF THE $F_{1}$ FEMALES PRODUCED LITTERS

\begin{tabular}{|c|c|c|c|c|c|c|c|}
\hline Group & $\begin{array}{c}\text { No. } \\
\text { animals }\end{array}$ & $\%$ & kind & $\begin{array}{l}F a t \\
(\%)\end{array}$ & $\begin{array}{l}\% \text { Survival } \\
\text { of young }\end{array}$ & $\begin{array}{l}\text { Litter weight } \\
\text { at } 20 \text { days }\end{array}$ & $\underset{\text { Age of } 50 \% F_{1}}{\text { reduction }}$ \\
\hline I & 60 & 12 & Casein & 10 & 85 & $70 \cdot 6$ & 84 \\
\hline $\begin{array}{l}\text { II-1 } \\
\text { II-2 } \\
\text { II-3 }\end{array}$ & $\begin{array}{r}11 \\
11 \\
5\end{array}$ & $\begin{array}{r}10 \\
8 \\
6\end{array}$ & $\begin{array}{l}\text { Casein } \\
\text { Casein } \\
\text { Casein }\end{array}$ & $\begin{array}{l}10 \\
10 \\
10\end{array}$ & $\begin{array}{c}66 \dagger \\
52 \ddagger \\
4\end{array}$ & $\begin{array}{l}44 \cdot 5 \dagger \\
44 \cdot 7 \dagger \\
15 \cdot 6 \dagger\end{array}$ & $\begin{array}{l}84 \\
88 \dagger \\
*\end{array}$ \\
\hline $\begin{array}{l}\text { III-1 } \\
\text { III-2 }\end{array}$ & $\begin{array}{l}10 \\
10\end{array}$ & $\begin{array}{l}12 \\
10\end{array}$ & $\begin{array}{l}\text { Casein } \\
\text { Casein }\end{array}$ & $\begin{array}{l}3 \\
2 \cdot 5\end{array}$ & $\begin{array}{l}59 \dagger \\
37 \pm\end{array}$ & $\begin{array}{l}43 \dagger \\
20 \cdot 4 \ddagger\end{array}$ & $\begin{array}{l}* \\
*\end{array}$ \\
\hline $\begin{array}{l}\text { IV-C } \\
\text { IV-1 }\end{array}$ & $\begin{array}{l}4 \\
9\end{array}$ & $\begin{array}{r}12 \\
8\end{array}$ & $\begin{array}{l}\text { Casein } \\
\text { Casein }\end{array}$ & $\begin{array}{l}10 \\
2 \cdot 5\end{array}$ & $\begin{array}{l}100^{\top} \\
100\end{array}$ & $\begin{array}{l}72 \\
34 \cdot 3 \ddagger\end{array}$ & * \\
\hline $\begin{array}{l}V-C_{1} \\
V-P \\
V-F_{1} \\
V-F_{2}\end{array}$ & $\begin{array}{l}56 \\
11 \\
17 \\
11\end{array}$ & $\begin{array}{r}9 \\
6 \\
16 \\
16\end{array}$ & $\begin{array}{l}\text { Corn } \\
\text { Corn } \\
\text { Mixed } \\
\text { Mixed }\end{array}$ & $\begin{array}{l}4 \\
2 \cdot 7 \\
8 \\
8\end{array}$ & $\begin{array}{l}81 \\
35 \neq \\
41 \dagger \\
79\end{array}$ & $\begin{array}{l}63 \\
16 \cdot 3 \ddagger \\
32 \cdot 1 \ddagger \\
52 \cdot 6 \dagger\end{array}$ & $\begin{array}{c}90 \\
180 \ddagger \\
120 \dagger \\
*\end{array}$ \\
\hline
\end{tabular}

* Not tested for reproduction.

$\uparrow$ Significantly lower than Group I controls $(P<0 \cdot 05)$.

$\ddagger$ Highly significantly lower than controls $(P<0.01)$.

averaging $6.6 \mathrm{~g}$ and litters averaging $44.7 \mathrm{~g}$ (Text-fig. 2). Reductions in survival and individual weights were highly significant $(P<0 \cdot 01)$. From twenty-three of these young maintained after 20 days on control feed, fourteen litters were born by the time the females were 90 days of age. By 120 days nineteen litters were born averaging 9.6 young, of which $51 \%$ survived to 20 days at which time individual and total litter weights were $9.2 \mathrm{~g}$ and $45 \mathrm{~g}$, respectively. Seven of the nineteen litters $(38 \%)$ failed during lactation. Delay in reproduction, reduced survival, and litter loss were highly significant $(P<0.01)$.

Further reduction of casein to $6 \%$ (Group II-3) produced most striking results. Five females on this ration maintained only two out of forty-six young to 20 days. Most litters survived for 10 days, but their numbers were progressively reduced. The two young which survived were from a litter of ten young of which eight survived to the 5th day, seven to the 10th day, and four to the 15 th day.

In all cases, weights of Group II survivors at 60 days of age maintained on control feed after 20 days were not significantly different $(P>0 \cdot 05)$ from those of controls.

Reduction of fat to $3 \%$ (Group III-1) for lactating females resulted in $59 \%$ pup survival (Text-fig. 1) to 20 days at which time individual weights were 
$5.3 \mathrm{~g}$ and the total litter weights were $43 \mathrm{~g}$ (Table 2$)$, significantly $(P<0.01)$ lower than the controls. The young, returned to control feed on Day 20, attained the control average $26 \mathrm{~g}$ weight at 60 days, but reproductive performance was not tested.

In order to determine further the limits of tolerance, another group (Group III-2) of ten females with new-born young was given a diet containing $10 \%$ casein and $2.5 \%$ fat. Only $37 \%$ of the young survived to 20 days (Text-fig. 1 ) at which time the individuals averaged $5 \cdot 1 \mathrm{~g}$ and the total litter $20.4 \mathrm{~g}$ (Text-fig. $2)$, or less than one-third that of the controls $(P<0 \cdot 01)$. The surviving young were distinctly underweight at 60 days of age; unfortunately, conditions in the laboratory did not permit maintenance for reproduction tests.

Reduction of a control group (Group IV-C) to five young on the day of parturition resulted in young weighing $15.2 \mathrm{~g}$ each and a total litter weight of 72 $\mathrm{g}$ on Day 20 (Text-fig. 2). Reduction of young of a similar group (Group IV-1) of nine females receiving $8 \%$ protein and $2.5 \%$ fat resulted in individual young weighing $6.9 \mathrm{~g}$ on Day 20 with total litter weights of $34.5 \mathrm{~g}$ (Text-fig. 2). Both individual and litter weights were significantly $(P<0.05)$ lower than those of controls. All young survived when litter size was reduced to five on the first day, and all reproduced normally.

Group V-C consisted of fifty-six females that received corn meal as the only protein source during lactation. At 20 days, individual and total litter weights were 8.7 and $63 \mathrm{~g}$, respectively, with $81 \%$ survival, not significantly $(P>0.05)$ different from control Group $I$. Females of the $F_{1}$ and $F_{2}$ generations maintained on a balanced laboratory chow averaged 92 days of age at first parturition and their young were not significantly different $(P>0.05)$ from the original litters. The parental experimental females, Group V-P, receiving $6 \%$ corn protein (two parts corn meal, one part corn starch) maintained only $35 \%$ of their young to Day 20, at which time the litters averaged $16.3 \mathrm{~g}$ (Table 2) and the surviving young averaged $5.1 \mathrm{~g}$, significantly lower than controls $(P<0 \cdot 01)$. Twenty-three of the Group V-F females maintained on a balanced laboratory chow after 20 days were mated to control males at 60 days. Only three of these females produced litters by 90 days, none of which survived. No other litters were born before 120 days and only eleven litters were born before 150 days. By 180 days, seventeen litters had been born, averaging 7.8 young each, of which $41 \%$ survived to 20 days with average individual and litter weights $7 \cdot 2$ and $32 \mathrm{~g}$. Delay in reproduction and low survival were highly significant $(P<0.01)$ and reduced individual and litter weights were significant $(P<0 \cdot 05)$. Eleven of twelve females of the Group $\mathrm{V}-\mathrm{F}_{2}$ generation produced litters averaging $9 \cdot 2$ young of which $79 \%$ survived to 20 days (Text-fig. 1 ) with individual and litter averages of 7.2 and $52.6 \mathrm{~g}$, respectively, significantly $(P<0.05)$ lower than those of controls. These eleven females, averaged 114 days of age at parturition, significantly $(P<0.05)$ longer than age at parturition of controls.

\section{DISCUSSION}

It is not possible to determine if part of the reductions in reproduction and growth of the young resulted from reduced feed intake although general 
observation and weights that were taken failed to show any difference in quantity of food consumed. In all cases, the feed mixes for experimental groups were made from the same stock, differing only in proportions, so whatever group differences that developed were direct results of the different concentrations of protein or fat being tested.

Reductions in the ability of females to maintain young resulted from diets deficient in either protein or fat, or both. The low casein diets resulted in lowered survival as well as reduced individual and total litter weights. The $10 \%$ casein diet resulted in a survival rate of $66 \%$ compared with $85 \%$ in the controls (Text-fig. 1). The total litter weights reflect a more striking $55 \%$ reduction, but almost complete recovery after 40 days on control feed. The $\mathrm{F}_{1}$ generation produced young which survived as well as the controls and weighed the same as the controls. The $8 \%$ casein diet reduced litters more drastically. Both survival rate and total litter weights were less than $65 \%$ of those of the controls. The young did not recover fully, resulting in the age at first parturition being significantly prolonged and survival of their offspring drastically reduced. Six per cent casein in the diet was below the requirement for litter survival, as only two of forty-six young survived. Those which did survive were apparently normal. All litters survived the first 5 -day period, but only two litters survived to Day 10 and two young in one litter beyond 15 days.

Another feature exhibited by the reduced casein group was the percentage of $F_{1}$ animals producing young by 120 days of age. Eighty per cent of the controls produced litters at an average age of 84 days. Of these only $8 \%$ failed to maintain litters until weaning. The $10 \%$ casein group (Group II-1) produced the same proportion of litters, but nearly $20 \%$ of these litters failed to survive. Only $70 \%$ of the $8 \%$ casein group (Group II-2) produced litters by 120 days with the average reproductive time of 93 days, significantly longer than the controls; the $37 \%$ litter failure during lactation was significantly $(P<0.01)$ greater than failures among controls.

Reduction of fat to $3 \%$ of the diet (Group III-1) resulted in reduction of survival to $70 \%$ that of the controls. Weights of surviving young and surviving litters were reduced to approximately $60 \%$ of those of controls.

Reduction of the rations to $10 \%$ casein and $2.5 \%$ fat (Group III-2) resulted in severely affected young, with only $44 \%$ of normal survival and $21 \%$ of control litter weights (Text-fig. 1). Comparably, Nelson (1959) stated that dietary protein must be above certain minimal levels $(10 \%)$ for full lactation and Mueller \& Gox (1946) found low protein diets (5 to $10 \%$ ) resulted in lower individual and litter weights. However, Curtiss (1953) stated that reduced protein resulted only in smaller animals and not a decrease in numbers, possibly because he was working with only a marginal deficiency. Strecker \& Emlen (1953) found that inadequate fat $(<4.5 \%)$ in the diet resulted in reduced survival of young as well as reduced weights of offspring.

Experimental evidence from Group IV supports the observations of Bateman (1954) in that reduction of litters increases the percentage survival as well as the weights of the young. When control litters were reduced to five young on the day of parturition, the surviving young were almost twice as large as normal controls, resulting in total litter weights being similar to those of the control 
litters (Text-fig. 2). Litters of females on $8 \%$ casein and $2.5 \%$ fat (Group IV-1) reduced to five on the day of birth failed to reach control levels, but all offspring survived and the average litter weight was $70 \%$ more than that of non-reduced litters on comparable rations although only half that of controls (Text-fig. 2). It appears that if litters are reduced to a low enough level, mothers are able to produce adequate milk to raise the remaining offspring normally and there are no repressions of reproduction passed on to the next generation as found by Chitty (1952) and Christian \& LeMunyan (1956) for social stress.

The strain of mice used in this series of experiments maintained normal growth and reproduction for at least four generations when fed whole grain yellow corn meal fortified with adequate minerals and vitamins in contrast to the deficiencies previously noted (Mitchell \& Smuts, 1932; Sauberlich \& Salmon, 1955). None of the samples of Group V feed contained more than $9.5 \%$ protein. Comparison of Group V-C results with Groups II-1 and 2 indicates that the mice used for this study utilized the corn protein more efficiently than they did casein.

Animals existing on low levels of corn protein, however, developed symptoms indicative of some deficiency other than low protein. Young of eleven females fed a $6 \%$ protein corn meal diet rapidly developed shaggy coats and wrinkled skin, and became weak and highly excitable. The survival rate was only $44 \%$ that of controls (Text-fig. 1) and the 20-day average litter weight was only $25 \%$ that of controls. The animals were unable to recover for normal reproductive function as only $41 \%$ of the $F_{2}$ generation survived (Text-fig. 1) in litters averaging $32 \mathrm{~g}$ at 20 days. There was a considerable time lapse before these animals produced litters with any regularity. Significant differences existed even through the third generation, in which the 20-day litter weight had recovered to $84 \%$ that of the controls. The survival rate of the $F_{2}$ young, however, approached the control level, $79 \%$ to $81 \%$ respectively (Text-fig. 1 ). Differences still existed in the time required for females to produce litters with regularity, the $F_{2}$ generation averaging 114 days of age at parturition compared to 92 days in the control group $(P<0.05)$ and 96 days for the $\mathrm{F}_{3}$ females.

The reduction of casein from $12 \%$ to $10 \%$ resulted in a significant reduction $(P<0.05)$ in reproductive performance. This reduction was significantly augmented by reducing the fat intake to $3 \%$. The amount of casein required to maintain even a minimum level of reproduction appeared to be $8 \%$ and the effects of such deficiencies were manifested for more than one generation. In contrast, corn meal, with $9 \%$ protein, was adequate to maintain full lactation for normal growth of the young, and $6 \%$ corn protein (with comparably reduced fat) proved to be only slightly more deficient than $8 \%$ casein with $10 \%$ fat or $10 \%$ casein with $2.5 \%$ fat.

The effects on the young of low protein or fat in the mother's diet must result from deficiencies either in quantity or quality of milk produced by the mother (Christian, 1956). Deficiencies in the milk, then, result in poor growth, either from starvation or lack of essential growth materials, such as essential amino acids or fatty acids. Total survival of the few young left in the reduced litters of Group IV-1, deficient in both protein and fat, Group II-2, deficient in protein and Group III, deficient in fat, indicates that the unreduced litter may be 
impaired by either insufficient or inadequate milk. No biochemical tests of mouse milk have yet been possible to determine proportions of essential constituents, although developing technology may soon provide the means of making such analyses on the few drops of milk obtainable.

Persistence of the effects of lactation deficiencies into subsequent generations indicates effects greater than simple starvation, which has been reported (Nelson, 1959) to be remedied in a short time by adequate diet. In the casein-fat deficient group (Group III-2), failure of so great a percentage of the litters distinctly indicated a fundamental weakness, the nature of which has not been found. The total loss of the first reproductive cycle and delay in the second in the mice nurtured on low corn protein (Group V) indicates a long-lasting effect from growth deficiencies not previously detected. However, such lasting weakness could have resulted from combined inadequacies of amino acids and essential fatty acids, since there was some reproduction delay in the group (Group III-2) that received reasonably adequate protein and low fat. Many more trials must be made to find the true solution.

Long term effects of low protein or chronic deficiency of essential amino acids is a completely different and more subtle problem than the acute shortage reported here. Preliminary trials of feeding growing young the low protein diets used for our experiments resulted in no reproduction. Pregnant females maintained on diets of $8 \%$ protein or less resorbed their young or ate them at birth, posing yet more problems and providing no material for lactation studies. Cowley \& Griesel (1959) reported slow growth and considerable mortality in suckling rats 12 to 24 days after birth by mothers that had been maintained from weanlings on a slightly below normal (about 13\%) protein feed. Also, they reported (Cowley \& Griesel, 1963) that a ration slightly higher in protein (about $14 \%$ ) resulted in fewer deaths and less retardation. Reproductive performance of the young suckled by deficient mothers was not reported, although they reported that the $\mathbf{F}_{\mathbf{1}}$ young, maintained on the low protein continuously, had measurably lower scores on reactions (Cowley \& Griesel, 1962).

The results of Cowley \& Griesel $(1959,1963)$ further emphasize the quality of proteins being tested, as their 'low protein' ration contained more protein than our 'high protein' ration. It could be they were testing the yellow maize meal $(56 \%)$ and milk powder $(16 \%)$ of their adequate diet against ground whole wheat $(75 \%)$ and dextrin $(7 \%)$ of the low protein ration, rather than actual protein content, as these items constituted the major differences between the rations.

Unfortunately, our state of knowledge and advanced techniques of nutrition studies are totally inadequate for a final analysis of effect of deficiencies on reproduction or growth, until a complete analysis of the ration is available, including trace minerals, vitamin and enzyme components and flavour. Consequently, it is necessary that as nearly as possible, one factor be measured at a time, and let the accumulation of facts reveal the true meaning.

\section{REFERENCES}

Bateman, N. (1954) The measurement of milk production of mice through preweaning growth of suckling young. Physiol. Zoöl. 27, 163. 
ChItтy, D. (1952) Mortality among voles (Microtus agrestis) at Lake Vyrnwy, Montgomeryshire in 1936-39. Phil. Trans. R. Soc. B, 236, 505.

Christian, J. (1956) Adrenal and reproductive responses to population size in mice from freely growing populations. Ecology, 37, 258.

Christian, J. \& LeMunyan, C. (1956) Adverse effects of crowding on lactation and reproduction of mice and two generations of their progeny. Endocrinology, 63, 517.

Cowley, J. J. \& GRIESEL, R. D. (1959) Some effects of a low protein diet on a first filial generation of white rats. 7. genet. Psychol. 95, 187.

Cowley, J. J. \& Griesel, R. D. (1962) Pre- and post-natal effects of a low protein diet on the behavior of the white rat. Psychologia Africana, 9, 216.

Cowley, J. J. \& Griesel, R. D. (1963) The development of second generation low protein rats. 7. genet. Psychol. 103, 233.

CurTiss, C. (1953) Effects of low protein intake on the pregnant rat. Metabolism, 2, 344.

French, E., Ingram, R., Knoebel, L. \& Swift, R. (1952) The influence of dietary fat and carbohydrate on reproduction and lactation in rats. 7 . Nutr. 48, 91.

Lauckhart, J. (1957) Animal cycles and food. f. Wildl. Mgmt, 21, 230.

MAYNARD, L. \& RASMussen, E. (1942) The influence of dietary fat on lactation performance in rats. F. Nutr. 23, 385.

Mrtahell, H. \& SMUTs, D. (1932) The amino acid deficiencies of beef, wheat, corn, oats, and soybeans for growth of the white rat. 7. biol. Chem. 95, 263.

Mueller, A. \& Cox, W., JR (1946) The effect of changes in diet on the volume and composition of rat milk. F. Nutr. 31, 249.

Nelson, M. (1959) Relation of dietary protein to reproductive physiology in female rats. In: Reproductive Physiology and Protein Nutrition, p. 2. Ed. J. H. Leathem. Rutgers University Press, New Brunswick, New Jersey.

SaUberlich, H. \& Salmon, W. (1955) Amino acid imbalance as related to tryptophane requirement of the rat. 7. biol. Chem. 214, 463.

Strecker, R. \& EmLen, J. (1953) Regulatory mechanisms in house mouse populations; the effects of limited food supply on a confined population. Ecology, 34, 375. 